\title{
EDUCATIONAL FACEBOOK USAGE CONTEXT: UNIVERSITY TEACHERS AND STUDENTS` POSITION
}

\author{
Vincentas Lamanauskas, Violeta Šlekienè, Loreta \\ Ragulienè \\ University of Šiauliai, Lithuania
}

\begin{abstract}
Social networking website development takes place rapidly and extensively. A fierce competition between different companies creating and supporting networking websites is going on. New ways are sought to attract potential consumers and to support those consumers. SNW usage in various organisations' activity does not raise any doubts, in fact. In Lithuania e.g., about $40 \%$ of inhabitants use social networking websites, and especially Facebook. Two things are obvious - the number of consumers is constantly growing, especially in the youth population and networks give new opportunities for organisations to expand and develop the activity. Thus, a grounded question arises for the Facebook, treating it as an ICT instrument (technology) - how to purposefully and effectively use the possibilities provided by this technology from an educational point of view. Intensive ICT implementation happens to be one of the most important factors in recent decades determining essential changes forming environment and quality of the studies in higher schools. It is likely, that Facebook as a social network might be effectively used in the study process. However, two essential and opposite moments collide here - Facebook as a waste of time and facebook as an effective educational tool.
\end{abstract}

Key words: Facebook, focus group, social networking websites, university studies.

\section{Introduction}

The use of technologies in education is inevitable. It is obvious, that rather many people, especially youth, actively use various social networks. Moreover, in the variety of social networks, Facebook keeps the leader's position, despite of the fierce social network competitive fight. Over the latter 10 years, quite a lot of researches have been carried out, related with social network usage, their influence on people's life and so on. In fact, two different positions can conditionally be discerned. Some think, that social networks negatively affect people's ability to critically think and independently accept decisions, make the other negative influence on personality, strengthen addiction, the perception of reality weakens. The others think on the contrary, claiming, that social networks is an inevitable thing, determined by the rapid technology spread, thus, provide a significant advantage. In spite of various discussions, facts are obvious. Almost all the people now, regardless of age, sex, education, income and social status, have profiles on the Facebook page. Also, quite a lot of people use the other social networks as well Google+, Twitter, Linkedin. The $1^{\text {st }}-4^{\text {th }}$ course student research, carried out in Lithuania showed, that students point out the following SN website advantages: the possibility to communicate with many people at one time, to get in touch with the people seen long ago also with the friends and relatives living abroad, the possibility to find proper information and share it, self-realization possibility, because one can freely express ideas, improve English language knowledge and virtual communication abilities, there is a possibility to find friends and new acquaintances. Respondents notice SN website disadvantages too, such as information publicity, lack of 
privacy, insecurity of presented data, possible lies, deceptions, there is a lot of inaccurate information, a possibility arises to get acquainted with bad people (Lamanauskas, Šlekienè, Ragulienè, 2012). A very similar research, carried out with Romanian university students showed, that the most frequently visited and most popular social networks among Romanian students are You Tube and Facebook; the majority of the respondents use social networking websites a few times a day; only a small part of the respondents know how social networking websites use published and other type of information; the usage of SNWs is related with the usage of computers and internet. Also the most important functions of SNWs for Romanian students are: communication (including communication in interest groups), learning and exchanging information, exchanging photos, video, friend search and texting (Iordache, Lamanauskas, 2013). A research, carried out in Lithuania also revealed some important psychological Facebook usage peculiarities in teenage population. The obtained results showed, that $81.1 \%$ of teens are users of the social network site Facebook and spend very much time on Facebook, publishing a lot of personal information in the web profiles without paying due attention to privacy preservation. On the website, adolescents accumulate large amounts of "friends", although relationship transfer from the reality to the Internet prevails (Pociūtè, Krencaitè, 2012).

It is obvious, that Social networking websites (SNW) are closely related with economical, psychological, educational, valeological and other aspects. Thus, can social networks effectively carry out educational function? Can they become a proper professional development instrument? We can formulate a lot of questions. The phenomenon of social networking websites is new and complicated, rapidly changing (Lamanauskas. 2012). More often the attention is paid to educational Facebook value. A serious lack of research on Facebook's use as an educational resource is obvious (Aydin, 2012). The number of this field research is getting bigger (Selwyn, 2009; Esteves, 2012; Ranieri, Manca, Fini, 2012). The researchers agree that Facebook is a frequently used Computer Mediated Environment (CME) for students and others to build social connections, with identities and deposited self-expression (Wang, Scown, Urquhart, Hardman, 2014).

The main aim of the research is to ascertain how teachers and students use facebook possibilities on educational purposes. It was also sought to analyze common teachers' and students' position from the point of view of social network usage (Facebook case).

\section{Research Methodology}

\section{General Research Characteristics}

The research is qualitative, of a pilot type. A survey version - Focus group interview was chosen for the research. The researchers think that the discussion going on in groups can disclose the opinions and attitudes which the respondents wouldn't tell in an individual interview (so - called group effect works here). Its results will be used for validity and construction of the main research instrument. The research was carried out in 2014, between January and February, in Siauliai University (Lithuania).

\section{Research Procedure, Participants, Data Analysis}

The research was carried out under the leadership of a moderator. The discussion procedure was fixated by an assistant moderator. Focus group research was carried out using traditional qualitative methods. Focus group assistant moderator used to write down the most important thoughts in the data list. During the discussion the moderator also used to put down the necessary remarks. A few principal rules were fixed. Seeking to keep and 
direct the discussion in the desired direction, certain methods were used during it, such as free associations, imaginative hypothetical situations, pretence in not knowing and wrongly understanding.

Two focus groups were formed. The first one contained Siauliai university Environmental science department teachers. The size of the group is 6 participants. All of them use different level of Facebook. The second focus group contained Siauliai university Educology faculty postgraduates. These were 8 Education quality management programme students; all of them use different level of Facebook. The discussion took place in one of the faculty auditoriums. So, 14 participants took part in the research, on the whole.

Data analysis was based on Krueger \& Casey (2000) methodology. The researchers applied structural analysis method for data analysis. In this stage, one gets acquainted with the data reading the notes (audio records were not made), reading full transcriptions several times, the remarks put down during the interview, and the summary written immediately after the interview. The data are analysed basing oneself on the criteria of words, context, inner consistency, frequency and extensiveness, commentary intensiveness, the exactness of the answers, "great ideas".

The analysis was carried out trying to systemically answer these questions:

- What Facebook usage advantages and disadvantages are known (noticeable) for the participants?

- What Facebook usage, on educational purposes, possibilities discern the participants?

- What Facebook, as a social network, functions would be important from the point of view of education?

- What educational and motivational Facebook value (meaning, importance) did the participants notice?

- Other notices and comments.

\section{Research Results}

\section{FOCUS group 1 - Siauliai University Environmental science department teachers}

Department teachers rather actively use FB page. The chief of the department noticed, that this social network is useful in general. The teachers agreed on a common position, that the main purpose of the department Facebook profile creation is students' search, i.e., advertising of the department and information hosting, seeking to attract the students to study programmes, organised by the department.

Some educational examples of the usage of Environmental science department Facebook profile have been singled out:

- Making a flower garden near the university building (the first House), a video film was made and hosted in FB as an informational - teaching material.

- A lot of department photos are hosted. If needed, one can easily find and use for the right purposes, e.g., various events, study fairs and so on.

- Some of the teachers create individual specialist communities, e.g., the teacher Dr. Gudzinskas has created the community page "Plant Systematics". A lot of photos and information about plants are hosted there.

During the discussion, the other FB usage examples were also pointed out:

- On Facebook it is easier to find the necessary student, e.g., using the student's personal profile. 
- Some of the teachers willingly accept the students as their personal friends in FB profile.

- The teachers think that this motivates the students, they like seeing their photos in e- space.

- The attention is drawn to the fact, that the other countries use FB more in the study process - an example FAGO IP - Swedish, Latvian and Lithuanian project.

Special attention in the discussion was devoted to possible negative FB usage aspects. Certain arguments came to light in the discussion, with which all participants agreed. The arguments, noticed by the teachers, because of unwillingness to use Facebook are as follows:

- Do not want to communicate with students after work. It is thought, that if necessary, it is more appropriate to answer by e-mail (asynchronously).

- It is agreed on a common position, that all electronic spaces are good for the work with students; it is accentuated that it is better to work in reality and in reality to communicate with students. Real communication cannot be changed by any social networks.

- It is warned about personal data safety, used on FB. The common opinion is that this FB usage aspect causes grounded concern.

- In Lithuania there is no tradition of FB usage for public purposes. Human resources are needed for this. For example, a special man is necessary, who would answer effectively to all questions appearing on the wall (e.g., on Siauliai University FB wall). In other words, seeking to maximally use FB provided possibilities, it is necessary to allot extra human resources for this.

In the discussion, it was sought to discuss and discern possible and probable FB usage possibilities in the study process. Having discussed various insights, such Facebook usage possibilities can be singled out:

- Students' realizable or already realized projects can be hosted here. It would be a perfect publicity device. Not only students could use such information but all interested people, in fact.

- A concrete community profile of teachers and students group for a separate subject or for a few subjects can be created, e.g., for pedagogical practice, professional practice, outdoor practice and so on. Such FB profile would not be personal, but more formal, devoted to certain educational and study purposes.

- There was a discussion about teachers' communication on Facebook. For example, organising department meetings, however, the majority did not accept that position thinking that it is necessary to organise real meetings.

Two very important moments emerged in the discussion which should appropriately be analysed more exhaustively:

- To analyse students' opinions about FB usage need in the study process. On the other hand, the teachers admitted that students might not know if they need, however their needs can be developed, possible advantage of FB usage in the study process can be shown.

- To analyse how often being on the internet the students connect to FB, and how often they check their e-mail.

\section{FOCUS group 2 - Siauliai University Educology faculty postgraduate students}

Students are not very active FB users. They think that this social network very easily and quickly spreads a certain type of information. Besides, this information is operative, 
handily available. Another thing is that very interesting information can be found, which is even not thought about beforehand. A very important advantage is free usage, common space, where one can publicise various information (share different information, using the possibility of loading photos, video recordings, share journey, personal and social life impressions). Students agree that using FB, communication is possible with different country citizens. One can look through various informative pages. Besides, it is possible to write a suitable message to all acquaintances. It has been stated, that FB helps to communicate with friends, find previous friends' contacts and to renew relationships. The possibility to communicate, get in touch and associate with friends, close people, relatives who live in different parts of Lithuania and the world, is considered a very important FB advantage. The students notice, that using FB is useful for reserved people, because it is easier for them to find friends, to develop communication skills (Facebook joins people).

Also, one can easier match study and work questions (this is urgent for extramural students). In this networking website study material, comments are shared and exchanged, discussive questions are raised and finally, it is being communicated with each other more than live (unfortunately). More often, in this networking website, one can get in touch with the teachers that prefer Facebook and not e-mail advantages. The majority of discussion participants agreed, that FB advantage related with studies does not need discussion at all, because the biggest part of students, being in the course, use Facebook.

The students agree that the main Facebook's advantage is an opportunity for people of any age, education and status to communicate, staying in any place of the world. The only condition is to have internet access and, of course, be able to use the computer. Students think that FB is useful for marketing - advertisement purposes as well, e.g., the possibility to popularise the establishment in which one works and studies, to invite the enterprise to events, exhibitions, to attain more visitors, to advertise goods and services.

Practical unlimitedness of information spread is considered one of FB disadvantages. Apparently, there is too much openness about a person, a lot of people too openly spread information about themselves, not always is definitely known who exactly one communicates with (person's privacy is lost too). Also, it has to be mentioned, that a person does not see, who and how many times visited his account, was interested in the information hosted there, and what intentions of the interested person were. Students think that this takes away a lot of productive time, can cause even addiction. The problem is with the signing out of a consumer network. The other Facebook's disadvantage worth mentioning is - too much of various advertising; personal or other completely unnecessary information abundance is observed. Very often the information is negative, its reliability is doubtful. Networking website determines "live" communication disappearance and propagation of the virtual one. In the time being, people using FB start hosting the biggest part of their life style, personal information, by which they can be reached by unknown people, because there is no possibility in the settings to guarantee and limit access, to save confidentiality.

From the educational point of view, the students do not discern special benefit, because they are not active users. They think that FB can be quite a good instrument for language learning in the communication with foreigners. Besides, one can send educational information from one consumer to another, and to see some international news. There are student groups in which they discuss the most important questions, report about homework and/or other educational tasks (e.g., tests). Students think that this is very useful. A person, searching for information, can get various suggestions, links to the other networking websites and so. Group creation according to interests or study programmes would be very purposeful. Then it would be very effective for students to communicate between each other. Different information related with the study process, provided by the educational 
institution, would be significant for extramural students. Various closed course and speciality Facebook groups can be and are created, in which information, visual material, tasks related with lectures and scientific activities are hosted.

Students think that sending information to each other and gathering information about a close and distant environment would be a sensible thing from educational point of view. This possibility is still poorly used by students. In their opinion, popularization would be an important function. On Facebook educational institutions have a possibility to introduce, popularize their institution, inform, announce the news, invite to various events, actions and so on. Some educational institutions have their accounts in this social network and make use of this possibility. Information can be presented both in the level of person to person and institution to person and so on. The advantage is that it is sufficient to host information in the group account and all group members can see it already, it does not have to be sent to each of them separately. Besides, feedback is possible, i.e. comment, reflexion. Students think that from educational point of view "to share" is an important function. It allows seeing a lot of visual and textual educational material. This is not necessarily direct study material, but world practice, examples, which allow to globally evaluating everything, seeing and later discussing or getting interested in one or another aspect in more details.

\section{Summing-up}

Generalising both focus groups' discussions, one can claim, that:

- Facebook's educational value despite of the mentioned advantages is not very big and educational possibilities are still not sufficiently used /revealed. More exhaustive investigations are necessary in this field.

- Facebook does not encourage to more exhaustively, deeper analyse presented information, very often superficially arranged material, information of a doubtful quality find their way here.

- Facebook forms very perfect possibilities for the formation of the groups of likeminded people in which both academic youth and scientific staff can communicate and cooperate sensibly. These can be professional, subject groups as well as groups according to different interests.

- Facebook can be useful if it is used thoughtfully and sensibly. Both students and teachers discern FB as a perfect instrument for study marketing and for educational institution image formation.

- Conditionally one can think that for teachers more urgent is their activity, separate study subdivisions' (e.g., department's) activity and publicity, visibility in society and a more relevant thing for the studying is information exchange between students as well as students and teachers. This is obviously related with the employment of the studying youth and distance study development.

\section{References}

Aydin, S. (2012). A review of research on Facebook as an educational environment. Educational Technology Research \& Development, 60 (6), 1093-1106.

Esteves, K., (2012). Exploring Facebook to Enhance Learning and Student Engagement: A Case from the University of Philippines (UP) Open University. Malaysian Journal of Distance Education, 14 (1), 1-15. 
Iordache, D., Lamanauskas, V. (2013). Exploring the Usage of Social Networking Websites: Perceptions and Opinions of Romanian University Students. Informatica Economica, 17 (4), 18-25. DOI: 10.12948/issn14531305/17.4.2013.02

Krueger, R. A., \& Casey, M. A. (2000). Focus Groups. A Practical Guide for Applied Research (3rd Edition). Thousand Oaks, CA: Sage Publications, 206 p.

Lamanauskas, V. (2012). Social Networking Websites: New Educational Space. Problems of Education in the 21st Century, 39, 5-7

Lamanauskas, V., Šlekienė, V., Ragulienè, L. (2012). Socialiniai tinklalapiai universitetų studentų požiūriu: naudojimosi ypatumai. Gamtamokslinis ugdymas / Natural Science Education, 1 (36), 8-16.

Pociūtè, B., Krancaitè, E. (2012). Paauglių aktyvumas vs. pasyvumas interneto socialiniame tinkle „Facebook“ ir sąsajos su jaučiamu vienišumu bei asmenybès bruožais [Adolescent activity vs passivity on social networking websites and its relations with loneliness and personality traits]. Psichologija, 46, 60-79.

Ranieri, M., Manca, S., Fini, A. (2012). Why (and how) do teachers engage in social networks? An exploratory study of professional use of Facebook and its implications for lifelong learning. British Journal of Educational Technology, 43 (5), 754-769.

Selwyn, N. (2009). Faceworking: exploring students' education-related use of Facebook. Learning, Media \& Technology, 34 (2), 157-174.

Wang, R., Scown, P., Urquhart, C., Hardman, J. (2014). Tapping the educational potential of Facebook: Guidelines for use in higher education. Education \& Information Technologies, $19(1), 21$.

Received 17 January 2014; Accepted 27 February 2014

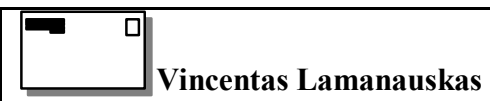

PhD., Professor, Natural Science Education Research Centre, Siauliai University, P. Visinskio Street 25-119, LT-76351 Siauliai, Lithuania.

E-mail: v.lamanauskas@ef.su.lt

Website: http://www.gutc.su.lt; http://lamanauskas.puslapiai.lt/

\section{Violeta Šlekiené}

PhD., Senior Researcher, Natural Science Education Research Centre, Siauliai University, P. Visinskio Street 25-119, LT-76351 Siauliai, Lithuania

E-mail: violeta@.fm.su.lt

Website: http://www.gutc.su.lt

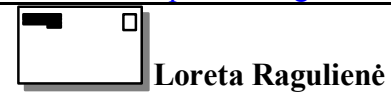

PhD., Senior Researcher, Natural Science Education Research Centre, Siauliai University, P. Visinskio Street 25-119, LT-76351 Siauliai, Lithuania

E-mail: 1oretar@gmail.com

Website: http:/ /www.gutc.su.lt 